\title{
LEGIT BOLTAS (Learning Gadget Bola Tata Surya) Based on Augmented Reality in SDI Raden Patah Surabaya
}

\author{
Rizqi Putri Nourma Budiarti ${ }^{*}$, Nur Fauziah ${ }^{2}$, Zahrotul Jannah ${ }^{3}$, Tri Nadia Ningsih ${ }^{4}$ \\ \{rizqi.putri.nb@gmail.com ${ }^{1 *}$, nurfauziah031.sd18@ student.unusa.ac.id ${ }^{2}$, \\ zahrotuljannah037.sd18@student.unusa.ac.id ${ }^{3}$, trinadia003.sd18@ student.unusa.ac.id ${ }^{4}$ \} \\ Information System, Engineering Faculty, Universitas Nahdlatul Ulama Surabaya ${ }^{1}$, S1 \\ Pendidikan Guru Sekolah Dasar, Fakultas Keguruan dan Ilmu Kependidikan, Universitas \\ Nahdlatul Ulama Surabaya ${ }^{2,3,4}$
}

\begin{abstract}
The learning process at the elementary school level in Indonesia requires the creativity of educators to improve literacy, learning motivation and effective learning outcomes, especially in natural science (IPA) learning materials, sometimes learning is applied in theory and presented abstractly so that it requires a high level of reasoning. Lack of creativity and application of educators at SDI Raden Patah Surabaya, especially in understanding the material of the Solar System makes learning not conducive, learning outcomes indicators do not experience development so that many students do not understand and are motivated to learn more deeply. This study aims to improve students' motivation and learning outcomes in Natural Sciences (IPA) subjects, especially in the case of the Solar System through the LEGIT BOLTAS media application in fifth-grade students of SDI Raden Patah Surabaya. This type of research is quantitative descriptive with experimental learning methods and using 4-E learning cycle model. The method usedis to compare the results of the pretest and posttest data collection techniques to the use ofLEGIT BOLTAS media. the application of planetarium media gives an increase in the value of student motivation in learning by $90 \%$. The result of this study showed that the application of the use of LEGIT BOLTAS (Learning Gadget of Bola Tata Surya) Based on Augmented Reality can increase motivation and learning of fifth-grade students of SDIRaden Patah Surabaya The learning energy used by students is directed to observe, analyze and differentiate the processes of revolution, rotation of the earth and other processes in the Solar System. From the results of this study, it is expected that the level of student understanding will increase in actualizing student creativity in terms of innovation and digitalization.
\end{abstract}

Keywords: Learning Media, Science, Concrete Operational Learning, Augmented Reality

\section{Introduction}

The development of qualified human resources is the initial capital of a nation to achieve the prosperity and welfare of its people. Developing quality human resources requires education and professional teaching staff. Education, Design, Movement, Movement and Movement of Humans to Improve Quality of Humans to Humans of All Qualities for Social and Religious Development [1]. While in the National Education System Law Number 20 on the year 2003 article 1 on paragraph 1 states that "Education is a conscious and planned effort to realize learning and learning processes so that students who actively develop the potential needed to 


\section{Kresna Social Science and Humanities Research}

Proceedings of the International Conference On Ummah:

Digital Innovation, Humanities And Economy (ICU: DIHEc) 2020 https://doi.org/1030874/ksshr.18

increase spiritual strength, help themselves, intelligence, noble character, as well as the necessary skills, society, nation and state.

In accordance with the law, learning that is able to develop students' potential is an activitybased learning process, where students become the main indicators of learning activities both cognitive and psychomotor [2]. As Turkmen states, "Experience that imitate those real scientists and is in accordance with the nature of science"[3]. Thus, students must be seen as organisms that are developing and have potential, where the task of educators is basically is to explore and develop the potential of students, not to repeat and cram learning material or force students to memorize data and facts [4].

In an effort to achieve quality education, the government has emphasized literacy and numeracy programs. One program that is being driven by the Ministry of Education and Culture (Kemndikbud) is the literacy movement, which means that in the Big Indonesian Dictionary [5] is the ability to write and read. However, literacy is also intended to be visual literacy or the ability to recognize and understand ideas that are conveyed visually.

But looking back on the condition of education in Indonesia, its literacy ability is still very low compared to neighbouring countries such as Vietnam and Thailand. This can be seen through data from the Ministry of Education and Culture [6] which released the achievement of the PISA (Program for International Student Assessment) on December 6, 2016, that the results of research in 2015 Indonesia reached 22.1 points which are still below the State average OECD (Organization for Economic Cooperation Development) countries.

One of the competencies tested by PISA is scientific literacy competence, PISA [7] explains scientific literacy as defined as the ability to use scientific knowledge, to identify, formulate, and draw conclusions from problems based on experiments and evidence to understand nature universe. The ability of scientific literacy at this time is one of the urgencies that should be a good priority in its completion through a tangible form of effective and more meaningful learning that is applied starting elementary school education. useful and can be applied in everyday life. The ability of scientific literacy emphasizes something scientific and empirical that is to connect newly discovered facts with information or findings that already exist or look for other facts to prove that facts are found it is an innovation or discovery [8] So the ability of scientific literacy is the ability to focus on scientific matters that are empirically logical and analyze so that they are able to draw the conclusions to believe in something and carry out what is decided. which has released by the Ministry of Education and Culture on December 6, 2016.

Table 1. Scientific literacy in PISA 2012, 2015, and 2018 between several country

\begin{tabular}{lrrrrrr}
\hline & \multicolumn{2}{c}{2012} & \multicolumn{2}{c}{2015} & \multicolumn{2}{c}{2018} \\
\hline Vietnam & median & average & median & average & median & average \\
Thailand & 531 & 528 & 522 & 525 & 543 & 543 \\
Indonesia & 441 & 444 & 416 & 421 & 421 & 426 \\
Brazil & 380 & 382 & 399 & 403 & 392 & 396 \\
Peru & 399 & 402 & 394 & 401 & 396 & 404 \\
Malaysia & 372 & 373 & 392 & 397 & 400 & 404 \\
OECD & 419 & 420 & 442 & 443 & 436 & 438 \\
\hline
\end{tabular}




\section{Kresna Social Science and Humanities Research}

Proceedings of the International Conference On Ummah:

Digital Innovation, Humanities And Economy (ICU: DIHEc) 2020 https://doi.org/1030874/ksshr.18

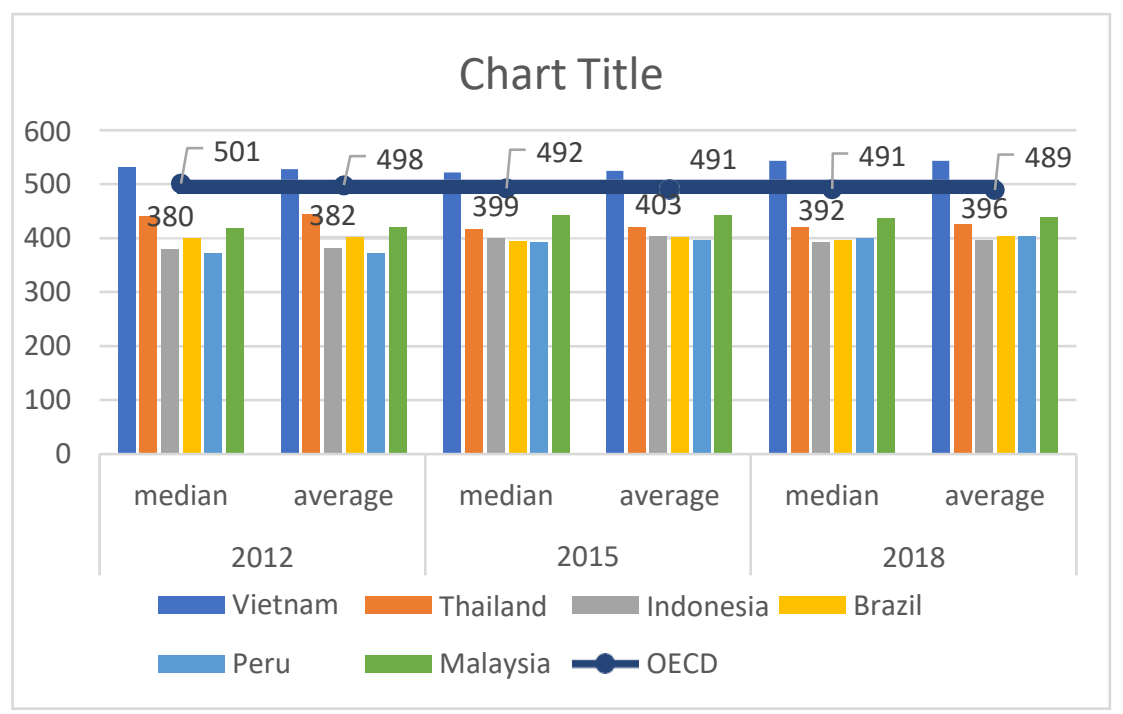

Fig. 1 Scientific literacy in PISA 2012, 2015, and 2018 between several country

Based on data from Table 1 and Fig. 1, it can be seen that the value of scientific literacy in Indonesia is still low, even below the OECD average. Indonesia got an average of 382 in 2012, 403 in 2015 and in 2018 it was at the level of 396 for the value of scientific literacy which has decreased compared to the results in 2015. When compared to other developing countries, Indonesia's score is still below the average compared to the newly independent Vietnam, with an average of 525 in 2015 and an increase of 543 in 2018. Thailand also experienced an increase of 421 on average in 2015 and experienced an increase in its average score of 426 in 2018. This is the reason why changes in how science literacy learning in Indonesia is needed in terms of increasing understanding of science material. The low level of scientific literacy can also affect students' low understanding and learning outcomes.

This happened in Surabaya to be precise at SDI Raden Patah Surabaya. Based on observations to obtain information related to scientific literacy in class V SDI Raden Patah Surabaya, it was obtained data that in the science learning process, especially in the material of the Solar System, some students did not understand. Class V has a total of 20 students with a percentage of $45 \%$ of students who have completed and $55 \%$ of students who have not.

Based on the results of interviews with Ms. Nurul as a science teacher at SDI Raden Patah Surabaya, there are several factors that cause low literacy and science learning outcomes, especially in the fifth-grade solar system, namely the learning model applied by educators who are still conventional and use the lecture method so that the explanation is only abstract without involving students in the learning process are the main factor for the low learning outcomes so that student motivation is reduced, especially in science literacy learning science. Even though the goals of education will be achieved if a teacher carries out learning in a professional manner. This is because a teacher must pay attention to references and learning indicators both in determining models, methods, materials, strategies, approaches, techniques, instructional media and other components [1].

In addition, the lecture method can only activate left brain functions related to students' abilities in terms of logic, short-term reading and writing material. However, in assimilating and 


\section{Kresna Social Science and Humanities Research}

Proceedings of the International Conference On Ummah:

Digital Innovation, Humanities And Economy (ICU: DIHEc) 2020 https://doi.org/1030874/ksshr.18

accommodating their knowledge, students still find it difficult. The second problem is the lack of creativity of educators in utilizing existing components to be used as concrete and effective learning media based on digital technology. So that most students become bored and not excited when learning takes place, some even fall asleep. Meanwhile, professional teachers are teachers who are able to think creatively and always develop the potential of their students [9]. And learning can be said to be effective if the right and left brain functions. The function of the right and left brain is an effort made to the maximum extent possible in educating students to achieve a balanced development [10].

Science learning, especially the material of the solar system, is not always packaged conventionally and is boring, with the teacher's learning model re-reading or explaining the material that already exists and must be mastered by students. For this reason, awareness is needed from educators that science learning is not fully intended for students to master learning material, but to create and foster the ability to think critically, systematically, and act scientifically. Based on Piaget's learning theory [11] that the stages of cognitive development of children aged 7-12 years or equivalent to elementary school children in concrete operations, at this stage the child's thinking process is directed at real and observable events. Students willget good learning outcomes if during the learning process they can understand the material well.The success of understanding the material is greatly influenced by the learning methods used by the teacher. When students participate actively both mentally, physically, and socially, the opportunity to understand the material for students will be even greater.

Based on these problems, a media innovation was made, namely LEGIT BOLTAS (Learning Gadget of Bola Tata Surya) in improving understanding and learning outcomes of solar system material for fifth-grade students of SDI Raden Patah. LEGIT BOLTAS (Learning Gadget of Bola Tata Surya) is a learning medium by utilizing waste from ice cream sticks, roll deodorizers and used lights to be used as a learning medium in understanding the concrete solar system and is effective and unique and environmentally friendly. In addition, the LEGIT BOLTAS is also equipped with the use of electronic electricity from a dynamo on a former solar lamp in the middle of the planets that students can observe in a concrete manner. So that in using Planetarium learning media, it can combine visual, auditory or kinesthetic learning models so that students understand the material presented more quickly. Because of this Planetarium learning media, students are not only able to memorize or remember visually.

However, students are more emphasized on basic literacy (Basic Literacy) to actualize themselves through direct and concrete observation in understanding, remembering, applying, analyzing, evaluating and being creative and students can classify in detail based on their own understanding of the location of the sun. systems and the application of the processes of revolution, rotation and events of day and night on planet Earth through the media they observe.

In addition, by using this learning media students are more sensitive in receiving understanding, and are able to respond actively, because innovative and creative learning is learning that can provide stimulation and cognitive interest that is effective in attracting students' attention [12]. Media Planetarium also developed Piaget's cognitive theory, grade V children (7-11 years) are at the concrete operational stage, meaning that at this stage the child can think logically and concretely which must be associated with real and concrete objects Santrock, 2009 (in Faizah et al. , 2017: 19). The application of LEGIT BOLTAS (Learning Gadget of Bola Tata Surya) in learning uses the 4-E Learning cycle model which is proven to increase student motivation, knowledge, and learning outcomes. This is supported by research by Oren \& Ramazan [13] that in this case, it should aim to improve students' scientific process skills, logical thinking skills, and a positive attitude towards science. One such approach is the learning cycle. The development of the LEGIT BOLTAS era (Learning Gadget of Bola Tata Surya) was developed by utilizing technology to become a student learning media based on Augmented 


\section{Kresna Social Science and Humanities Research}

Proceedings of the International Conference On Ummah:

Digital Innovation, Humanities And Economy (ICU: DIHEc) 2020 https://doi.org/1030874/ksshr.18

Reality (AR). With the hope that it does not limit understanding in actualizing student creativity, so that the role of students in the Industry 4.0 and Society 5.0 era can make students active, productive and innovative, especially for personal learning and its usefulness to the community, especially in the era of the COVID-19 pandemic.

Based on existing problems, such as how the application of LEGIT BOLTAS (Learning Gadget of Bola Tata Surya) as an effective learning medium about the introduction of the solar system to student learning outcomes at SDI Raden Patah Surabaya? How are the student learning outcomes after applying the LEGIT BOLTAS (Learning Gadget of Bola Tata Surya)? Thisstudy expects several benefits including for students, which are expected to improve learning outcomes and understand the concept of learning the solar system, for teacher educators it is hoped that it can be used as input to improve the quality of learning for students on solar system material, especially SDI Raden Patah Surabaya as the object of research, where the results This research is used as a tool for evaluation and correction, especially in improving the quality of learning and the quality of school services in science learning, one of which is learning the solar system.

Many study and previous works have been developed and published about literacy in educational using Augmented Reality (AR) as learning educational using technology while combining of virtual environment and real objects using interaction and implementation using 3D objects, which is many benefits of using AR technology in educational learning such as increasing student motivation because its fun learning using AR expecially while learning science literacy like Abdussalem, et all, 2018 that using AR technology called MicrosAR application to the student in science laboratory to examine microscopic organisms based on inquiry-based learning[14]. Liou, et all, 2017 also using AR technology as the references objects for the movement of the moon and compare it with VR technology[15]. Another benefitof using AR technology are increased student to be more active and raising attention of learning and willingly to participation and focused on learning activity because its provide a sense of reality that student can have it.

Learning theory in educational is related to the Operational Learning Concrete Learning model such as LEGIT BOLTAS as an effective learning media. According to learning theory of Piaget, Vygotsky, Bruner, Bandura and Contructivistic Learning theory. There are several study that focused on educational learning theory.

\section{Piaget's Learning Theory}

Jean Piaget is one of the Swiss-born psychology figures who was credited with finding a model that can describe humans to act in search of information to make sense of their world by collecting data and organizing information. The theory of Piaget influences many theories of contemporary development [16]. The characteristics of cognitive development of children according to Piaget include:

a. Children are active learners. In here, Piaget believes that every child not only observes and remembers what they have seen and heard passively, but naturally children have high curiosity and try to find information to help understand the reality they face,

b. Children organize what they learn from their experiences. It means that every child has experiences in their lives, each of them experiences not only gathering information that he gets but children can also learn good information and apply it in their daily lives.

c. Children adjust to the environment through the process of assimilation and accommodation. It showed that Assimilation occurs when the child inserts new knowledge or new information he knows into existing knowledge, whereas accommodation occurs when the child adjusts to new information.

d. The equilibration process shows an increase towards more complex forms of thinking. According to Piaget after a child has gone through the assimilation stage and the cognitive system accommodation stage will develop to the next stage which is the 


\section{Kresna Social Science and Humanities Research}

Proceedings of the International Conference On Ummah:

Digital Innovation, Humanities And Economy (ICU: DIHEc) 2020 https://doi.org/1030874/ksshr.18

aquilibration stage. Aquilibration is a balanced state between the structural structure and the child's experience of the environment.

It can be concluded that the main characteristics in the Concrete Operational stage are reversible transformation and the eternal system [17]. This means that children have developed logical thinking that can be applied in solving concrite problems that they face.

\section{Vygotsky's Learning Theory}

Vygotsky argues that higher mental functions include the ability to direct memory and attention for specific purposes and the ability to think in symbols are behaviors that require media. Based on the theory, the application of the Concrete Operational model with LEGIT BOLTAS media as an effective learning media will help students to gain knowledge about the world that exists in our nature, especially the solar system.

\section{Bruner's Learning Theory}

Bruner's learning theory is an active process that allows humans to discover new things beyond existing information. If someone learns a knowledge will be directly processed by the mind. Based on this theory students are expected to be active while in class. With LEGIT BOLTAS media as solar system learning, students can have knowledge about the solar system and the knowledge is not only abstract but real and also concrete.

\section{Others Relevant research}

As for several and previous studies that are relevant to this research, namely:

1. Research results from Abdul Azis, Dwi Yulianti and Langlang Handayani [18], states that the application of cooperative teaching models by utilizing physical science teaching aids (solar system material) can improve learning outcomes and collaboration of VII grade students at MTs NU 23 Salafiyah Syafiiyah Wonodadi Plantungan Kendal Semester II Academic Year 2005/2006.

2. The results of research from Endarmadi Kunto Wibisono[19], state that the implementation of the Augmented Reality application as a teaching aid in learning the physics of the solar system aims to make students more interested in the learning material delivered by teachers in class, so that indicators of the teaching and learning process can be achieved .

3. Research results from Ni Wyn. Juniasih, I Nym. Jampel and Ni Md. Setuti[20] states that the Concrete Operational learning model can improve the learning outcomes of students in class IV in Elementary School Group V, Tegallalang District, Gianyar Regency in 2012/2013.

4. The results of research from Angga Maulana and Wahyu Kusuma[21], states that the application of Augmented Reality (AR) as a solar learning media is very helpful for students to find out information about the solar system and as a combination of objects and cyberspace in the real environment.

5. Research results from Ni Nym. Wdyasari, Ni Wyn. Rati, Nym. Kusmariyatni [22], stated that the learning model with Concrete media had a positive effect on the learning outcomes of Mathematics students in class V in Elementary School Cluster IX, Gianyar subdistrict, Kianyar Regency 2016/2017 Academic Year.

\section{RESEARCH METHODOLOGY}

In this research, there are two methods that focused on the use of AR technology in science education to provide the solution of the the problem. Firstly, the methods of implementation of Augmented Reality and the second is the methods of learning design in science education. 


\section{Kresna Social Science and Humanities Research}

Proceedings of the International Conference On Ummah:

Digital Innovation, Humanities And Economy (ICU: DIHEc) 2020 https://doi.org/1030874/ksshr.18

\subsection{Research Method of Augmented Reality}

The solution methods of AR that in this research used which consist of seven step: (1) 3D reconstruction model using 3D Object, (2) Marker Selection, (3) Tecture and Animation, (4) Code Program, (5) Integrated AR application using vuforia library, (6) Visualize AR application and (7) Analize the system using usability testing. In this research, making $3 \mathrm{~d}$ object design by analyzing what $3 \mathrm{~d}$ objects are needed, which includes the material of the solar system sphere, three-dimensional object design, markers used, application integration and application visualization to be produced. At the design stage of the $3 \mathrm{~d}$ object to the resulting application visualization, the analysis process of the system usage is continued and evaluated so that it becomes an application that is in accordance with the problem analysis of research conducted at SDI Raden Patah Surabaya. The next stage is the analysis phase as part of the testing where, the Augmented Reality-based LEGIT BOLTAS application will be tried out on 5th grade students of SDI Raden Patah Surabaya as users, this test is carried out to adjust the quality of users and usability of the applications used by students.
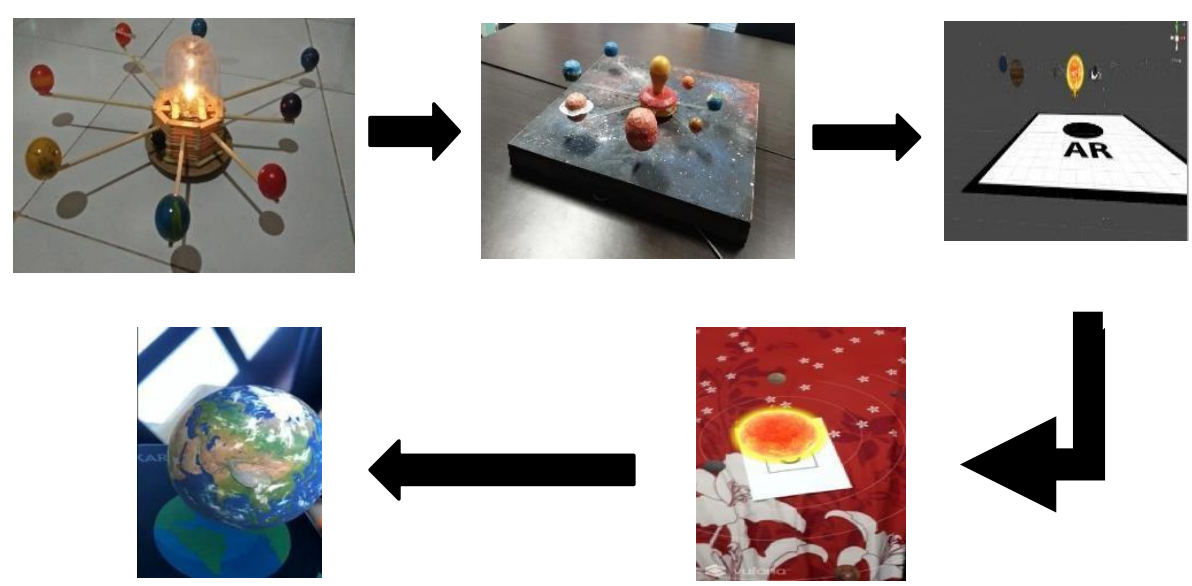

Fig. 2. Media Class product and LEGIT BOLTAS using AR technology

\subsection{Research Method of Learning Design in Science Literacy}

This research is using a quantitative research with experimental method. "The experimental research methodis a research method used to look for the effect of certaintreatments on other under controlled conditions" according to (Sugiyono, 2016: 13). The experimental design used was concrete operational learning in the using research instrument pretest-posttest.

Before doing the research each class was given a pretest to find out the initial analysis before media class product using conventional and AR was given to the two classes. The experimental class was given treatment (X) that is a playing the Augmented Reality (AR) for study science literacy in planet learning model using LEGIT BOLTAS as an Effective Technology - Based Media Class Product in Increasing Science Literacy in SDI RADEN PATAH SURABAYA during the learning process while the control class was not given the treatment of the application of the Augment Reality (AR) learning model For Planet as an Effective Learning Media in the Introduction to the Solar System in SDI RADEN PATAH 


\section{Kresna Social Science and Humanities Research}

Proceedings of the International Conference On Ummah:

Digital Innovation, Humanities And Economy (ICU: DIHEc) 2020 https://doi.org/1030874/ksshr.18

SURABAYA, but by applying conventional learning models. Then both classes were given a posttest to find out the effect of the treatment that was given.

\subsection{Data Collection Techniques}

In this research, we used several techniques in data collection such as documentation, questionnaires, observation, interviews and tests for evaluation of the system

1. Documentation. In the documentation techniqueis a technique for finding data relating to factors in the formof notes, news papers, transcripts, books, magazines, agendas, and soon [23]. In this study, the documentation technique was used to find out the data of fifth grade students in SDI RADEN PATAH

2. Questionnaire (questionnaire). In the questionnaire techniqueis a method for gathering information which is done by an alyzing the characteristics of a person to be measured[24]. Research ersuse this questionnaire technique to find out the learning model that is usually used by teachers during the teaching and learning process.

3. Observation. In the observation is an activity of an alyzing an object that is done by using the eyes of there spondents are small respondents, work processes, human behavior [25]. In this study, the observation used was structured observation. Whati s observed in the place of research whichis designed to makesys tematic observations [24]. Observation is used by researchers to observe the activities of teaching and learning in the classroom conducted by the teacher.

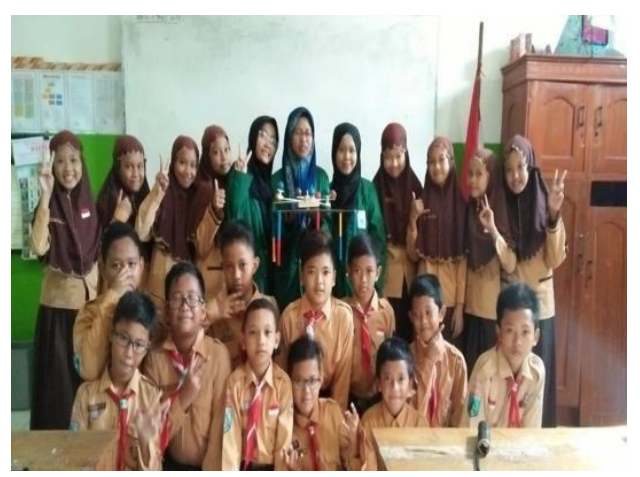

(a)

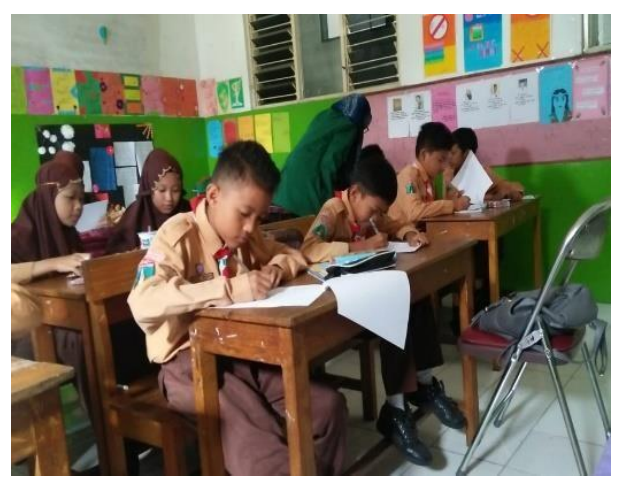

(b)

Fig. 3. (a)Conventional Learning Models and (b) AR Learning Models

4. Interview is a data collection technique used by researcherst of in problem sand preliminary studies[24]. In this study, researchers conducted interviews with home room teachers and students.

5. Test. In this stage, we used testing as data collection of research instruments which collected from a several of questions used to measure the knowledge, intelligence, ability, or talent and softskills that possessed by individuals or in groups[26]. In this 


\section{Kresna Social Science and Humanities Research}

Proceedings of the International Conference On Ummah:

Digital Innovation, Humanities And Economy (ICU: DIHEc) 2020 https://doi.org/1030874/ksshr.18

study, the test techniqueused was a pretest and posttest question consisting of 10 multiple choice questions with 4 answer choices.

\subsection{Research Instruments}

The research instrument is a tool used tome a sure research variables[1]. The instrument used in this study was a matter of pretest and posttest in the form of multiple choice to assess the learning outcomes of students who came. In addition to research instruments, researchers also prepare learning tools, starting from the syllabus, Learning Implementation Plan (RPP), textbooks, student books, student worksheets, and question lines. The instruments used by the researchers are Pretest and posttest. Testes are a number of questions that have right and wrong[27]. Pretest is a benchmark used by researchers before posttest. While the posttest is a benchmark used to evaluate. The instrument used test questions that used to analysis for experimental procedure in this study were a matter of pretest and posttest. The test questions are in the form of possing the problems and definition questions. As an analysis from the implementation of Augmented Reality (AR) for planet using the 4-E Learning Model. The learning of 4-E Learning Model method was first recognized by Robert Karplus in 1947 and experienced motivation so that it became 4-E learning. In accordance with the name of the model 4-E learning consists of 4 phases, namely Exploration, Explanation, Expansion, and Evaluation. Eachphase in this cycle has the oretical support from Jean Piaget's theory of cognitive development and appliescon structivist learning procedures. The implementation mechanis of LEGIT BOLTAS using the 4-E learning model can be seen in the following figure:

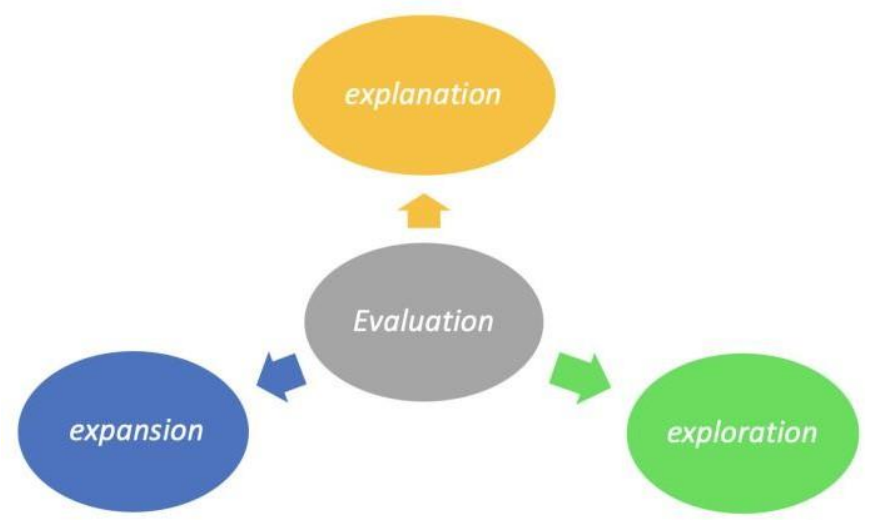

Fig. 4. Learning model 4-E learning cycle

The learning cycle approach as one of the approaches in learning is expected to support the improvement of scientific process skills, critical thinking skills and positive science. Oren \& Ramazan[13] revealed that "In this reason, in there needs new approaches which must a imtoimprove students' scientific processskills, logical thinking a bilities, creativity, critical 


\section{Kresna Social Science and Humanities Research}

Proceedings of the International Conference On Ummah:

Digital Innovation, Humanities And Economy (ICU: DIHEc) 2020 https://doi.org/1030874/ksshr.18

thinking skills, positive attitude to ward science. One of the learning approaches is the learning cycle.

\section{RESULT AND DISCUSSION}

This study analyses and evaluates the effect of two methods in similar design observation system in conventional based on media class learning and using media AR technology which are more effective to the student while understanding science literacy. The research focused on the measurement of learning outcome in terms of knowledge about science literacy expecially in solar system.

\subsection{Research Result}

The results of this study are based on data obtained from research activities carried out on 24 and 29 May 2019 at SDI Raden Patah Surabaya with the aim of fifth-grade class research being divided into 20 students, then divided into 2 groups of the same size (10 students). On May 24, 2019 researchers applied the current conventional learning model on May 29, 2019 the learning model used learning using fixed media spanning on the subject of the solar system. The results of this study are published:

1. Learning plans and indicators

Learning plans and learning indicators of media implementation for Augment Reality (AR) to study solar system or planet as an effective technology-based media with concrete operational learning methods with 4-E cycle learning mode.

Table 2. 4-E Learning Cycle Model in Learning Direction and Activities

\begin{tabular}{|l|l|l|l|l|}
\hline No & \multicolumn{1}{|c|}{ Fase } & \multicolumn{1}{|c|}{$\begin{array}{c}\text { Learning } \\
\text { Direction }\end{array}$} & \multicolumn{1}{|c|}{ Teacher Activities } & \multicolumn{1}{c|}{ Student Activities } \\
\hline 1. & Explanation & $\begin{array}{l}\text { 1. Analyzing the } \\
\text { initial knowledge } \\
\text { students have }\end{array}$ & $\begin{array}{l}\text { 1. Awaken curiosity. } \\
\text { 2. Asking questions. } \\
\text { 3. Exploring student } \\
\text { knowledge. }\end{array}$ & $\begin{array}{l}\text { 1. Recalling material } \\
\text { that has been owned. } \\
\text { 2. Answering questions } \\
\text { raised by teachers } \\
\text { based on the } \\
\text { knowledge they have } \\
\text { acquired. }\end{array}$ \\
\hline 2. & Expention & $\begin{array}{l}\text { 1. Observe the } \\
\text { LEGIT BOLTAS } \\
\text { media. } \\
\text { 2. Exchanging } \\
\text { information } \\
\text { regarding } \\
\text { understanding. } \\
\text { 3. Provide } \\
\text { opportunities for } \\
\text { students to gather } \\
\text { information. }\end{array}$ & $\begin{array}{l}\text { 1. Supervise students } \\
\text { discussing information } \\
\text { about the solar system. } \\
\text { 2. Encourage students } \\
\text { to work together in } \\
\text { groups } \\
\text { 3. Give time to students } \\
\text { to solve problems. }\end{array}$ & $\begin{array}{l}\text { 1. Give their opinions } \\
\text { on questions raised by } \\
\text { the teacher using the } \\
\text { LEGIT BOLTAS media }\end{array}$ \\
& & $\begin{array}{l}\text { 2. Group discussion } \\
\text { 3. Answering } \\
\text { problems. }\end{array}$ \\
\hline
\end{tabular}

ISSN 2774-3918 (online), https://ksshr.kresnanusantara.co.id. Published by Kresna Nusantara 


\section{Kresna Social Science and Humanities Research}

Proceedings of the International Conference On Ummah:

Digital Innovation, Humanities And Economy (ICU: DIHEc) 2020 https://doi.org/1030874/ksshr.18

\begin{tabular}{|c|c|c|c|c|}
\hline 3. & Exploration & $\begin{array}{l}\text { 1. Analyze and } \\
\text { explain what has } \\
\text { been gained in the } \\
\text { explore phase. } \\
\text { 2. Conduct an } \\
\text { assessment of } \\
\text { aspects of } \\
\text { knowledge and } \\
\text { knowledge skills } \\
\text {. }\end{array}$ & $\begin{array}{l}\text { 1. Encourage students } \\
\text { to present the results of } \\
\text { group discussions. } \\
\text { 2. Provide questions } \\
\text { with LEGIT BOLTAS } \\
\text { media so that students } \\
\text { can remember more } \\
\text { easily. }\end{array}$ & $\begin{array}{l}\text { 1. Present the results of } \\
\text { the discussion or } \\
\text { practice the results of } \\
\text { the discussion. } \\
\text { 2. Using concepts and } \\
\text { knowledge that has } \\
\text { been obtained }\end{array}$ \\
\hline 4. & Evaluation & $\begin{array}{l}\text { 1. use concepts } \\
\text { that have been } \\
\text { obtained before } \\
\end{array}$ & $\begin{array}{l}\text { 1. Guiding students to } \\
\text { use concepts that have } \\
\text { been obtained in new } \\
\text { situations as } \\
\text { applications. }\end{array}$ & $\begin{array}{l}\text { 1. Using concepts that } \\
\text { have been obtained by } \\
\text { students into new } \\
\text { situations as } \\
\text { applications that are } \\
\text { learned both from one } \\
\text { concept to another and } \\
\text { in everyday life. }\end{array}$ \\
\hline
\end{tabular}

2. Questioner (questionnaire) Student Response .

This questionnaire is used to determine student responses after applying the LEGIT BOLTAS learning media. Validation of students' responses to the science learning material the solar system has been validated by experts. b. Control class learning outcomes data Control class data obtained from the results of initial and final learning after using conventional learningmodels from Class V students consisting of 2 groups of 10 each Student Student learning outcomes use test-shaped match 5 questions and description 5 questions. Student gets a score of 1 Answer Correctly and Get a Score of 0 . From the data obtained can be obtained as follows:

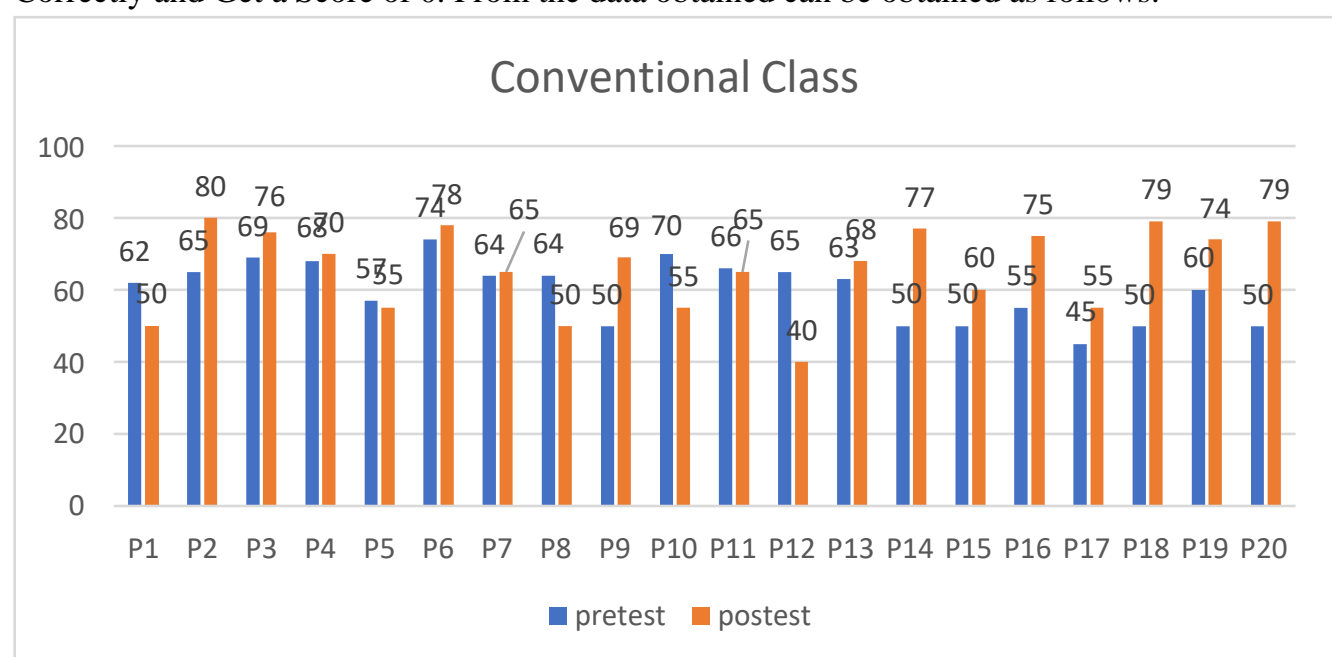

Fig. 5. Pretest and Posttest results of conventional media class 


\section{Kresna Social Science and Humanities Research}

Proceedings of the International Conference On Ummah:

Digital Innovation, Humanities And Economy (ICU: DIHEc) 2020

https://doi.org/1030874/ksshr.18

\subsection{Data on the learning outcomes of the experimental class}

Experimental class data were obtained from the initial and final class results after participating in learning using Augment Reality (AR) for Planet based on augment reality (AR) technology and concrete operational learning methods in the 4-E learning cycle learning model. With the assessment of learning outcomes as a control class. From the data obtained can be explained as follows:

\section{Experimental Class with AR}

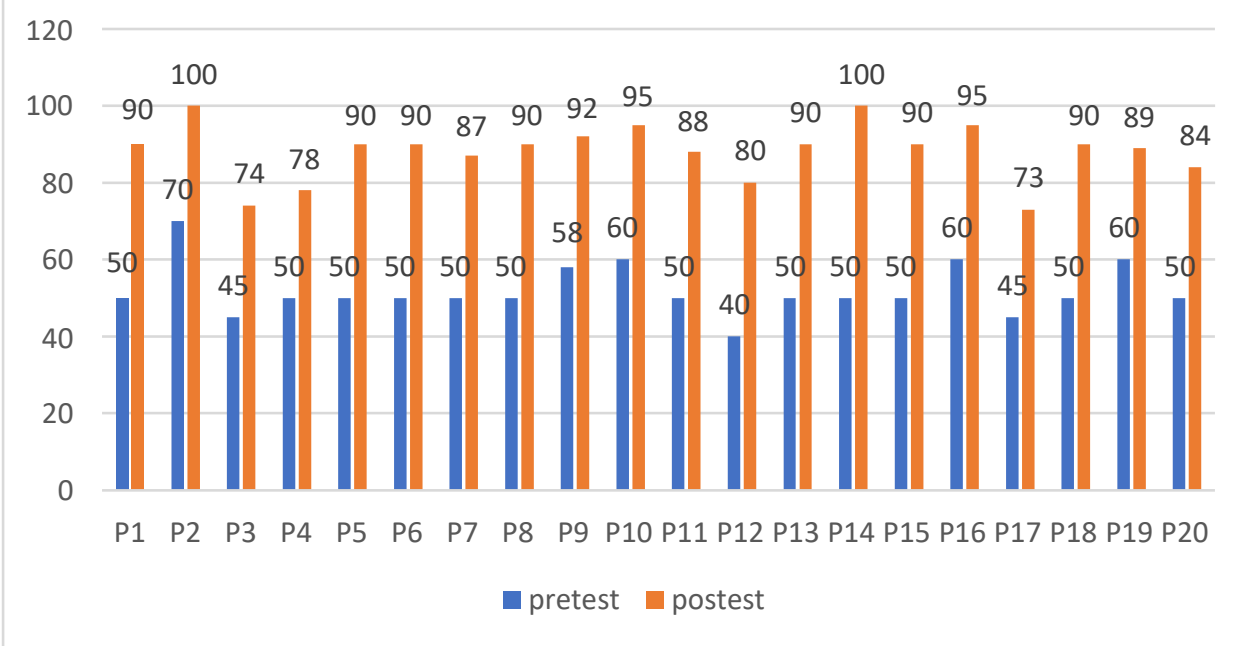

Fig. 6. Pretest and Posttest results of the AR experimental class
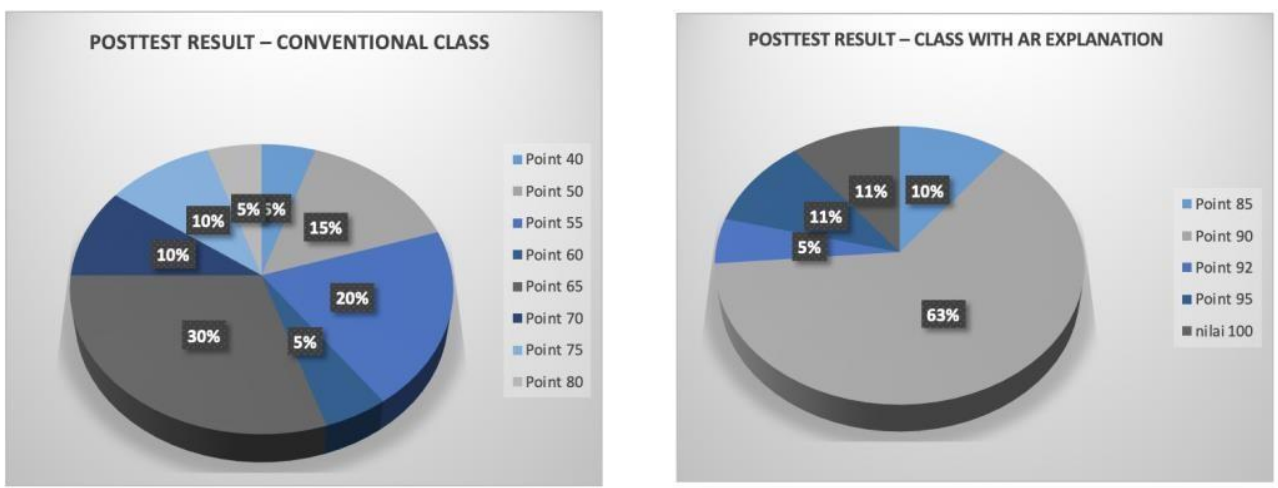

Fig. 7. Results of the comparison of posttest scores between the conventional class and experimental using AR technology classes

Based on the above data it can be concluded that the learning outcomes obtained by students have increased, which are categorized into two types namely complete and incomplete. Students who are said to have completed their learning outcomes are students who get a Pretest 


\section{Kresna Social Science and Humanities Research}

Proceedings of the International Conference On Ummah:

Digital Innovation, Humanities And Economy (ICU: DIHEc) 2020 https://doi.org/1030874/ksshr.18

and Posttest score of $\geq 70$ according to the KKM value set by the school. Instead students who are said to be incomplete are students who get a Pretest and Posttest score $\leq 70$.

\subsection{Usability of Acceptance AR technology}

Usability testing aims to see how easy it is to use the application by users of the LEGIT BOLTAS application. The test was carried out using a system usability scale questionnaire consisting of 10 questions and answer choices with a value of 1-5 starting from strongly disagree (SD), disagree (D), neutral (N), agree (A) and until strongly agree (SA) on each question. The questionnaire was distributed to 20 user respondents. The number of respondents used in functional testing and usability testing was taken based on data from Nielsen which stated that the number was more than the minimum limit for conducting testing effectively and efficiently[28]. The results of the usability test can be seen in Table 3. From the results of the questionnaire, the average value of the usability scale based on the questionnaire was 81.40 , which means it was included in the above average classification.

Table 3. The Result of Usability Testing

\begin{tabular}{rccccccccccr}
\hline & Q1 & Q2 & Q3 & Q4 & Q5 & Q6 & Q7 & Q8 & Q9 & Q10 & Average \\
\hline P1 & 3 & 5 & 3 & 5 & 4 & 4 & 4 & 5 & 3 & 5 & 4.10 \\
P2 & 4 & 3 & 4 & 4 & 3 & 5 & 3 & 5 & 5 & 4 & 4.00 \\
P3 & 4 & 3 & 4 & 3 & 4 & 3 & 4 & 5 & 4 & 3 & 3.70 \\
P4 & 3 & 5 & 5 & 3 & 4 & 4 & 5 & 4 & 4 & 5 & 4.20 \\
P5 & 5 & 5 & 5 & 5 & 5 & 5 & 5 & 5 & 5 & 5 & 5.00 \\
P6 & 4 & 3 & 4 & 4 & 3 & 4 & 5 & 5 & 5 & 5 & 4.20 \\
P7 & 3 & 3 & 5 & 5 & 4 & 3 & 5 & 5 & 4 & 4 & 4.10 \\
P8 & 5 & 3 & 5 & 5 & 3 & 4 & 5 & 5 & 4 & 4 & 4.30 \\
P9 & 4 & 3 & 4 & 4 & 4 & 3 & 5 & 5 & 4 & 4 & 4.00 \\
P10 & 5 & 3 & 5 & 5 & 3 & 4 & 4 & 5 & 3 & 3 & 4.00 \\
P11 & 3 & 4 & 3 & 3 & 4 & 4 & 5 & 5 & 3 & 3 & 3.70 \\
P12 & 5 & 5 & 3 & 3 & 3 & 3 & 5 & 4 & 4 & 3 & 3.80 \\
P13 & 5 & 5 & 5 & 5 & 5 & 5 & 5 & 5 & 4 & 3 & 4.70 \\
P14 & 4 & 3 & 3 & 4 & 3 & 4 & 5 & 3 & 4 & 5 & 3.80 \\
P15 & 4 & 4 & 3 & 3 & 5 & 5 & 4 & 3 & 3 & 4 & 3.80 \\
P16 & 4 & 5 & 3 & 3 & 5 & 3 & 3 & 3 & 3 & 4 & 3.60 \\
P17 & 3 & 5 & 3 & 3 & 4 & 4 & 5 & 5 & 4 & 3 & 3.90 \\
P18 & 5 & 4 & 4 & 4 & 4 & 4 & 4 & 4 & 5 & 4 & 4.20 \\
P19 & 5 & 3 & 4 & 4 & 3 & 5 & 5 & 5 & 4 & 4 & 4.20 \\
P20 & 5 & 4 & 3 & 5 & 3 & 3 & 4 & 4 & 5 & 5 & 4.10 \\
\hline & 191.40 \\
\hline
\end{tabular}

ISSN 2774-3918 (online), https://ksshr.kresnanusantara.co.id. Published by Kresna Nusantara 


\section{Kresna Social Science and Humanities Research}

Proceedings of the International Conference On Ummah:

Digital Innovation, Humanities And Economy (ICU: DIHEc) 2020 https://doi.org/1030874/ksshr.18

Based on Tabel 3. Usability result of functional testing, all the features in the LEGIT BOLTAS application can run properly according to the needs of both tablets and smartphones based on Android. Usability testing through a questionnaire resulted in the conclusion that user satisfaction got $81.4 \%$, which means that this application can run well according to its features and can help the process of recognizing planetary objects as media based on AR technology.

Table 4. Mean and Standart Deviation of Question from Usability testing

\begin{tabular}{lcc}
\hline Questions & \multicolumn{2}{c}{ AR } \\
\hline Usefulness & Mean & St.D \\
$\begin{array}{l}\text { Q1. I can understand how to use this application easily. } \\
\begin{array}{l}\text { Q4. I feel that the functions in this application are well } \\
\text { integrated. }\end{array}\end{array}$ & 4.15 & 0.81273 \\
User satisfaction attitude & 4 & 0.8584 \\
$\begin{array}{l}\text { Q8. I feel very confident when using this application. } \\
\text { Q10.Using this applications, I can observe all the planet and } \\
\text { excited }\end{array}$ & 4.5 & 0.76089 \\
\hline
\end{tabular}

These results of Table 4 suggested that the student from Experimental Class using AR technology tended to have positive perceptions that may influence the task performance. These results presented in the results of the learning performance, which indicated that students from Experimental Class using AR technology had better in the term of Usefulness and User satisfaction attitude.

\subsection{Result Discussion}

From the data and analysis above the following discussion can be obtained the differently result of conventional class and experimental class with AR technology learning outcomes data. Based on the results of Pretest and Posttest in class V on the first day of research on May 20, 2019 using conventional learning models obtained an average pretest result of 41.5 meaning students did not know, while the average posttest result of 61.5 with the highest value of 80 means students lack understanding and mastering the material of the solar system. Where the teacher only conveys learning in one direction without involving students directly and without the existence of a concrete and effective learning media. So, students do not understand the material by just listening to the teacher's explanation. May 21, 2019 as an experimental class obtained an average Pretest value of 51.9 with the highest value of 70 meaning that only a few students knew about the material of the solar system. So that one of the efforts to improve learning outcomes by applying the media Augment Reality (AR) For Planet, after the application of these media students are given a posttest. The average posttest results obtained by 90.6 or 91 with the highest value of 100 and the lowest value of 80 means that almost all students in the experimental class already understand the material of the solar system. Students whose grades are still below the KKM (score) 70) are 0 people, 2 people get the KKM standard

ISSN 2774-3918 (online), https://ksshr.kresnanusantara.co.id. Published by Kresna Nusantara To view a copy of this license, visit https://creativecommons.org/licenses/by/4.0/. 


\section{Kresna Social Science and Humanities Research}

Proceedings of the International Conference On Ummah:

Digital Innovation, Humanities And Economy (ICU: DIHEc) 2020 https://doi.org/1030874/ksshr.18

score and 2 people score 100. It can be concluded that the application of the media Augmented Reality (AR) for planet can improve student learning outcomes by the difference of pretest and posttest values of 38.7 .

\section{CONCLUSION}

Based on the results of this study it can be concluded that the implementation LEGIT BOLTAS as an effective media in learning the solar system at SDI Raden Patah Surabaya can increase interest, motivation and results of the fifth-grade class student in elementary school and it shows that learning process is understable with the concrete method operational learning and 4-E learning model consisting of 4 phases namely Exploration (Exploration), Exploration (Explanation), Exploration (Expansion), and Evaluation. Every phase in this cycle has support theoretical theory of cognitive development from Jean Piaget and apply constructivistic learning procedures. In the Exploration phase (Explanation) students discussing each other giving their opinions on questions that are proposed by the teacher using LEGIT BOLTAS media and answering problems that have been given. The conventional method of learning control class evaluation tools in the form of pretest and posttest and the difference is only $20 \%$ increase in value highest 80 , meaning that students do not understand and master the material of the solar system. While the experimental class that uses the difference AR technology media $40 \%$ So it can be concluded that the increase in learning outcomes using LEGIT BOLTAS media can increase by up to $90 \%$. Usability testing through a questionnaire resulted in the conclusion that user respondent satisfaction got $81.4 \%$, which means that this application can run well according to its features and can help the process of recognizing planetary objects as media based on AR technology.

\section{ACKNOWLEDGEMENTS}

We acknowledged that this research has been fund by Universitas Nahdlatul Ulama Surabaya.

\section{References}

[1] P. Sugiyono, "Metodologi penelitian kuantitatif kualitatif dan R\&D," Alpabeta, Bandung, 2011.

[2] S. Haryoko, "Efektivitas pemanfaatan media audio-visual sebagai alternatif optimalisasi model pembelajaran," J. Edukasi Elektro, vol. 5, no. 1, 2012.

[3] H. Türkmen, "How should science be taught by using learning cycle approach in elementary schools," Elem. Educ. Online, vol. 5, no. 2, pp. 1-15, 2006.

[4] W. Sanjaya, "Strategi pembelajaran berorientasi standar proses pendidikan," 2019.

[5] T. P. K. B. B. Indonesia, "Kamus besar bahasa Indonesia," Jakarta: Balai Pustaka, 2008.

[6] K. Pendidikan, "Kebudayaan, 'Peringkat dan Capaian PISA Indonesia Mengalami Peningkatan," Off. Website Kementeri. Pendidik. dan Kebud.

[7] F. Ahmadi and H. Ibda, Media Literasi Sekolah: Teori dan Praktik. CV. Pilar Nusantara, 2018.

[8] N. F. Rizki, D. Gusrayani, and A. Sujana, "PENERAPAN PEMBELAJARAN 


\section{Kresna Social Science and Humanities Research}

Proceedings of the International Conference On Ummah:

Digital Innovation, Humanities And Economy (ICU: DIHEc) 2020 https://doi.org/1030874/ksshr.18

BERBASIS MASALAH PADA MATERI SUMBER DAYA ALAM UNTUK MENINGKATKAN LITERASI SAINS SISWA SD,” J. Pena Ilm., vol. 2, no. 1, pp. 251-260, 2017.

[9] L. W. Anderson, B. S. Bloom, and others, A taxonomy for learning, teaching, and assessing: A revision of Bloom's taxonomy of educational objectives. Longman, 2001.

[10] M. Yaumi, Pendidikan karakter: landasan, pilar \& implementasi. Prenada Media, 2016.

[11] M. H. Olson and B. R. Hergenhahn, "Theories of learning," Jakarta: Kencana, 2009.

[12] R. A. Sani, "Pembelajaran saintifik untuk implementasi kurikulum 2013." Bumi Aksara, 2014.

[13] F. IcSalcsmaz Ören and R. Tezcan, "The Effectiveness of the Learning Cycle Approach on Learners' Attitude toward Science in Seventh Grade Science Classes of Elementary School," Elem. Educ. Online, vol. 8, no. 1, 2009.

[14] M. S. Abdusselam, S. Kilis, Ç. IcSahin Çaklir, and Z. Abdusselam, "Examining Microscopic Organisms under Augmented Reality Microscope: A 5E Learning Model Lesson," Sci. Act., vol. 55, no. 1-2, pp. 68-74, 2018.

[15] H.-H. Liou, S. J. H. Yang, S. Y. Chen, and W. Tarng, "The influences of the 2D imagebased augmented reality and virtual reality on student learning," J. Educ. Technol. Soc., vol. 20, no. 3, pp. 110-121, 2017.

[16] D. Desmita, Psikologi perkembangan peserta didik. Remaja Rosdakarya, 2009.

[17] J. Piaget and B. Inhelder, The psychology of the child. Basic books, 2008.

[18] A. Azis, D. Yulianti, and L. Handayani, "Penerapan model pembelajaran kooperatif dengan memanfaatkan alat peraga sains fisika (materi tata surya) untuk meningkatkan hasil belajar dan kerjasama siswa," J. Pendidik. Fis. Indones., vol. 4, no. 2, 2006.

[19] E. K. Wibisono, "Implementasi Aplikasi Augmented Reality Sebagai Alat Peraga Dalam Pelajaran Fisika Materi Tata Sury," Universitas Muhammadiyah Surakarta, 2011.

[20] N. W. Juniasih, I. N. Jampel, and N. M. Setuti, "Pengaruh Model Pembelajaran Think Talk Write (TTW) Berbantuan Media Konkret Terhadap Hasil Belajar IPA Siswa Kelas IV SD," Mimb. PGSD Undiksha, vol. 1, no. 1, 2013.

[21] A. Maulana and W. K. Raharja, "Aplikasi Augmented Reality sebagai Media Pembelajaran Tata Surya," Pros. KOMMIT, 2014.

[22] N. N. Widyasari, N. W. Rati, and N. Kusmariyatni, "Pengaruh Model Pembelajaran Tai Berbantuan Media Konkret Terhadap Hasil Belajar Matematika Siswa Kelas V,” Mimb. PGSD Undiksha, vol. 5, no. 2, 2017.

[23] A. Suharsimi, "Prosedur penelitian suatu pendekatan praktik," Jakarta: Rineka Cipta, 2006.

[24] U. Cahyana and R. A. Maolani, "Metodologi Penelitian Pendidikan," Jakarta PT Raja Graf. Persada, 2015.

[25] P. Sugiyono, "Metode Penelitian Manajemen(Pendekatan Kuantitatif, Kualitatif, Kombinasi (Mixed Methods), Penelitian Tindakan (Action Research, dan Penelitian Evaluasi).” Bandung: Alfabeta Cv, 2016.

[26] R. Kariadinata, "Dasar-dasar statistik pendidikan.” CV Pustaka Setia, 2015.

[27] D. Mardapi, "Teknik penyusunan instrumen tes dan nontes," Yogyakarta: Mitra Cendekia, vol. 127, p. 88, 2008.

[28] J. Nielsen, "Usability 101: Introduction to usability. Nielsen Norman Group. 2003." 2018. 